Rajmund TRZEBIA TOWSKI*, Tomasz HEESE**, Jerzy WISZNIEWSKI*

\title{
FORMS OF WHITEFISH, COREGONUS LAVARETUS (L.) IN LAKE MIEDWIE FORMY SIEI COREGONUS LAVARETUS (L.) JEZIORA MIEDWIE
}

\author{
*Institute of Aquaculture and Fishing \\ Techniques \\ **Institute of Ich thyology \\ Szczecin
}

\begin{abstract}
The whitefish (Coregonuslavaretus) of the Lake Miedwie was studied. Based on gill raker counts, three forms of the species are discerned: lavaretus, maraena, and generosus. The maraena form individuals showed the highest growth rate. The other two forms grew more slowly, their growth rates being similar to each other. The maraena and generosus forms fed on both plankton and benthos, while lavaretus consumed betnhos only.
\end{abstract}

\section{INTRODUCTION}

The increasing standard of life of the society results in a growing demand for high quality products. Among freshwater fish species, only the valuable ones are sought more and more. The whitefish, Coregonus lavaretus (L.) is one of such species. It occurs, albeit in declining abundance, in water bodies of northern Poland. Problems concerning the whitefish fishery in lakes involve obtaining suitable stocking material as well as deteriorating water quality.

The data on the Lake Miedwie whitefish reported in this study should be, at present, regarded as historical as the species is extinct in the Lake. The ecological catastrophe which took place in the Lake in summer 1975 (Stankiewicz and Mutko, 1978) resulted in a complete deoxygenation of water below $12 \mathrm{~m}$ depth and a mass mortality of the indigenous whitefish ensued. Single specimens were being sporadically caught until as late as 1985 (Mastyński, 1986). One should, however, consider the importance of these data which demonstrate the Lake Miedwie potential for whitefish production in the area. 
The Lake Miedwie whitefish was frequently dealt with by researchers interested in coregonids. Lityński (1932), Thienemann (1935), Wiese (1938), Steinmann (1951) and Gąsowska $(1965,1967)$ published a number of interesting information.

The present work is aimed at determining the taxonomic structure, food, and growth rate of the Lake Miedwie whitefish population.

\section{MATERIAL AND METHODS}

The fish individuals examined were caught in the Lake Miedwie between August 3, 1973 and May 15, 1974 (Table 1) with both moved (smelt trawl, seine) and stationary (Peter net) gears. A total of 373 individuals about $68 \%$ of which were caught in autumn winter were examined.

Table 1

Number of whitefish individuals caught in various months

\begin{tabular}{|l|c|c|c|c|c|c|c|c|c|c|}
\hline \multicolumn{1}{|c|}{ Year } & \multicolumn{3}{c|}{1973} & \multicolumn{3}{c|}{1974} \\
\hline Month & VIII & IX & X & XI & XII & I & II & III & IV & V \\
\hline $\begin{array}{l}\text { No. of whitefish } \\
\text { individuals }\end{array}$ & 15 & 21 & 46 & 75 & 119 & 54 & 19 & 11 & 8 & 5 \\
\hline Total & & & & & & & & & & \\
\hline
\end{tabular}

The meristic analysis to distinguish taxonomic forms was based on the gill raker count (as determined from the first gill arch), number of scales along the lateral line, and number of scales above and below the lateral line.

The fish individuals examined measured (total length) from 16.2 to $70.2 \mathrm{~cm}$. The fish were weighed to $5 \mathrm{~g}$. Fish age was determined from scales taken from above the lateral line between the dorsal and adipose fins. Growth rate was calculated from direct measurements.

The food analysis involved composition of food and frequency of planktonic and benthic organisms in diet. Food organisms were identified with the aid of a freshwater fauna key (Rybak, 1971).

\section{AREA OF STUDY}

The Lake Miedwie is one of the largest West Pomeranian lakes (Fig. 1). At present the Lake is a rudiment of a huge water body existing in the place 120 years ago and occupies on third of the latter's area. The Lake covers 3527 hectares; its maximum and mean depths are 43.8 and $19.3 \mathrm{~m}$, respectively. Until recently, the Lake was classified as 


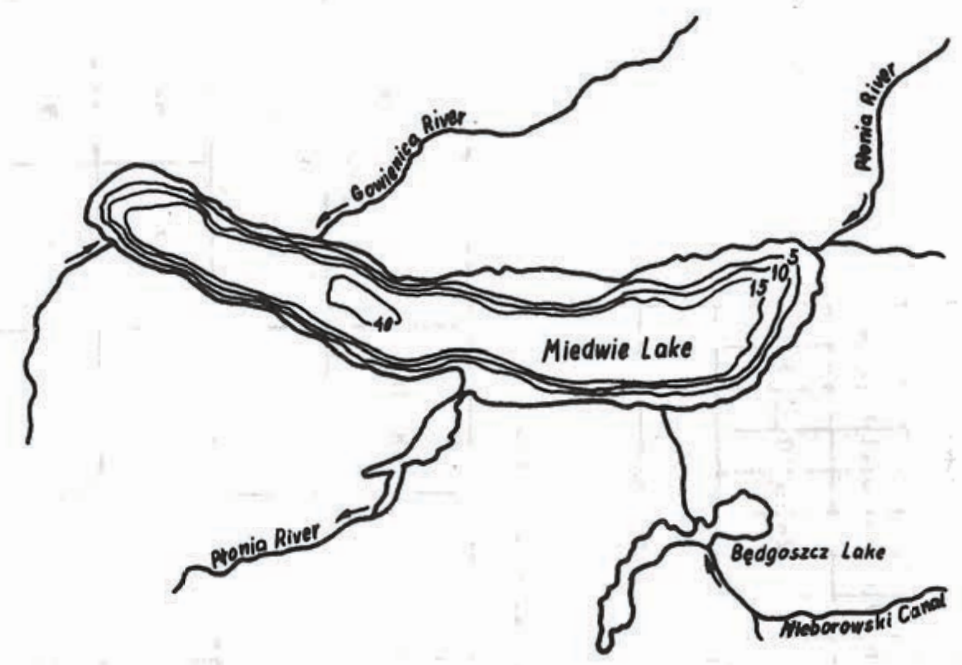

Fig. J. Lake Miedwie, with bathymetric data

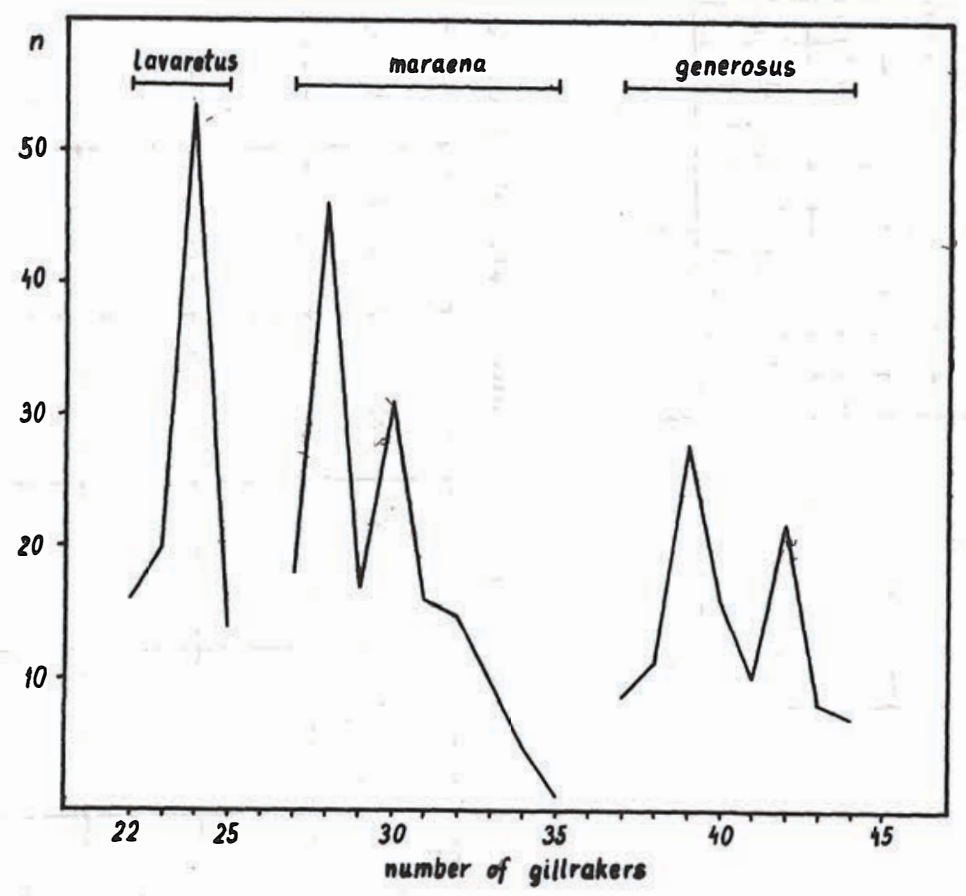

Fig. 2. Distribution of gill raker counts $(n=373)$ 
Table 2

Frequency of occurrence of whitefish with different gill raker counts

\begin{tabular}{|c|c|c|c|c|c|c|c|c|c|c|c|c|c|c|c|c|c|c|c|c|}
\hline $\begin{array}{l}\text { Whitefish } \\
\text { form }\end{array}$ & \multicolumn{4}{|c|}{ lavaretus } & \multicolumn{9}{|c|}{ maraena } & \multicolumn{7}{|c|}{ generosus } \\
\hline Gill rakers & 2223 & 24 & 25 & 26 & 27 & 28 & 29 & 3031 & 32 & 33 & 34 & 35 & 36 & 37 & 38 & $39 \mid 40$ & 041 & 42 & 43 & 44 \\
\hline $\begin{array}{l}\text { No. of } \\
\text { individuals }\end{array}$ & 1620 & 54 & 14 & - & 18 & 46 & 17 & $31 \mid 16$ & 15 & 10 & 5 & 1 & - & 8 & 11 & 2816 & $6 \mid 10$ & 22 & 8 & 7 \\
\hline Mean & & 3.6 & & & & & & 29.6 & & & & & & & & 40.3 & & & & \\
\hline
\end{tabular}

Table 3

Frequency of occurrence of whitefish with different number of scales along lateral line

\begin{tabular}{|c|c|c|c|c|c|c|c|c|c|c|}
\hline $\begin{array}{l}\quad \begin{array}{l}\text { No. of } \\
\text { scales }\end{array} \\
\text { Form }\end{array}$ & $79-81$ & $82-84$ & $85-87$ & $88-90$ & $91-93$ & $94-96$ & $97-99$ & $100-102$ & $\mathrm{n}$ & mean \\
\hline lavaretus & 2 & 6 & 39 & 23 & 19 & 11 & 4 & - & 104 & 88.5 \\
\hline maraena & - & 10 & 30 & 53 & 42 & 24 & - & - & 159 & 89.0 \\
\hline generosus & - & - & 8 & 10 & 32 & 42 & 12 & 6 & 110 & 94.5 \\
\hline
\end{tabular}


mesotrophic; at present, as demonstrated by oxygen conditions and contents of phosphates and ammonia in the hypolimnion, increasing eutrophication is observed (Tadajewski and Mutko, 1980). The process is reflected in changes in the hypolimnion oxygen content ( $1 \mathrm{~m}$ above the bottom) during the peak summer stagnation: from $6 \mathrm{mg} \mathrm{O}_{2} / \mathrm{dm}^{3}$ in 1963 to $0.8 \mathrm{mg} \mathrm{O}_{2} / \mathrm{dm}^{3}$ in 1978 (Tadajewski and Mutko, 1980).

\section{RESULTS}

\section{Gill raker counts}

The analysis of gill raker counts demonstrated the existence of three forms in the population, the forms differing markedly in their counts (Table 2; Fig. 2). Following Berg

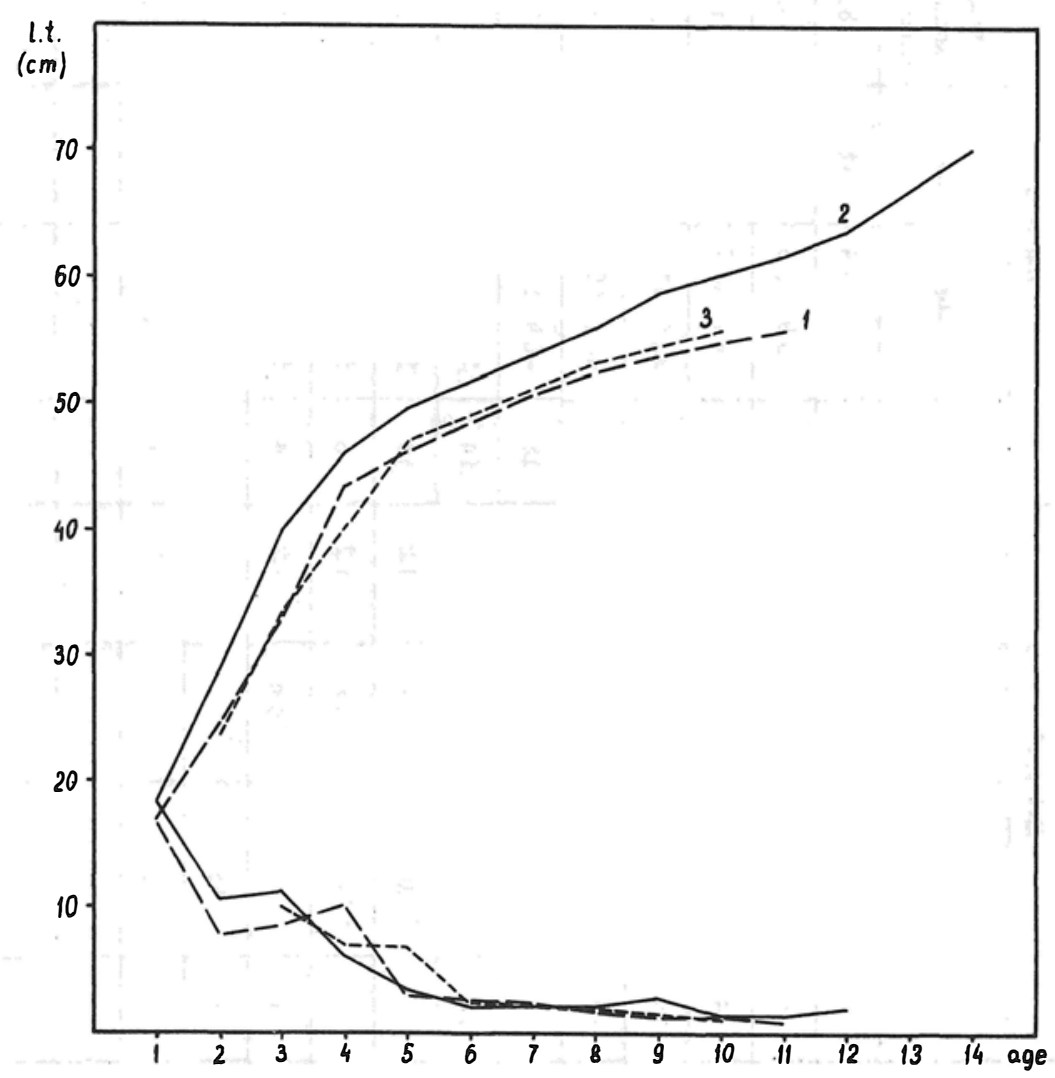

Fig. 3. Growth rate of three whitefish forms and their mean annual increments $1=f$. lavaretus; $2=f$. maraena $; 3=f$. generosus 
Table 4

Total length (1.t., $\mathrm{cm}$ ) growth rate in different whitefish

\begin{tabular}{|c|c|c|c|c|c|c|c|c|c|c|c|c|}
\hline forms & \multicolumn{4}{|c|}{ lavaretus } & \multicolumn{4}{|c|}{ maraena } & \multicolumn{4}{|c|}{ generosus } \\
\hline age group & $\mathrm{n}$ & range & mean & $\begin{array}{c}\text { mean } \\
\text { annual } \\
\text { increment }\end{array}$ & $\mathrm{n}$ & range & mean & $\begin{array}{c}\text { mean } \\
\text { annual } \\
\text { increment }\end{array}$ & $\mathrm{n}$ & range & mean & $\begin{array}{c}\text { mean } \\
\text { annual } \\
\text { increment }\end{array}$ \\
\hline I $\$$ & 5 & $15.1-18.5$ & 16.8 & 16.8 & 19 & $16.2-20.4$ & 18.3 & 18.3 & - & - & - & - \\
\hline II & 8 & $22.1-27.1$ & 24.6 & 7.8 & 17 & $23.9-32.5$ & 28.7 & 10.4 & 11 & $22.5-24.5$ & 23.5 & - \\
\hline III & 14 & $29.1-37.1$ & 33.1 & 8.5 & 24 & $34.1-48.7$ & 39.9 & 11.2 & 14 & $30.1-36.7$ & 33.4 & 9.9 \\
\hline IV & 15 & $41.5-44.9$ & 43.2 & 10.1 & 20 & $44.2-47.8$ & 46.0 & 6.1 & 7 & $38.3-41.1$ & 40.2 & 6.8 \\
\hline V & 13 & $44.4-48.0$ & .46 .2 & 3.0 & 15 & $48.1-50.8$ & 49.5 & 3.5 & 26 & $44.4-49.4$ & 46.9 & 6.7 \\
\hline VI & 23 & $47.1-49.9$ & 48.5 & 2.3 & 18 & $46.9-53.6$ & 51.6 & 2.1 & 23 & $47.4-50.6$ & 49.0 & 2.1 \\
\hline VII & 16 & $50.1-51.1$ & 50.6 & 2.1 & 14 & $52.7-54.9$ & 53.8 & 2.2 & 20 & $49.2-53.3$ & 51.2 & 2.2 \\
\hline VIII & 5 & $51.0-53.8$ & 52.4 & 1.8 & 18 & $54.0-57.8$ & 55.9 & 2.1 & 7 & $52.4-54.1$ & 53.1 & 1.9 \\
\hline IX & 3 & $52.8-54.2$ & 53.6 & 1.2 & 6 & $58.0-59.4$ & 58.7 & 2.8 & 1 & 54.5 & 54.5 & 1.4 \\
\hline $\mathrm{X}$ & 1 & 54.8 & 54.8 & 1.2 & 4 & $59.1-61.3$ & 60.2 & 1.5 & 1 . & 55.6 & 55.6 & 1.1 \\
\hline XI & 1 & 55.7 & 55.7 & 0.9 & 2 & $60.8-62.4$ & 61.6 & 1.4 & - & - & - & - \\
\hline XII & - & - & - & - & 1 & 63.6 & 63.6 & 2.0 & - & - & - & - \\
\hline XIII & - & - & - & - & - & - & - & - & - & - & - & - \\
\hline XIV & - & - & - & - & 1 & 70.2 & 70.2 & - & - & - & - & - \\
\hline
\end{tabular}


(1948) and Kaj (1962), three subspecies can be separated: Coregonus lavaretus maraena (Bloch, 1779), C.l.generosus (Peters, 1875), and C.l.lavaretus (L., 1758).

At the present state of knowledge on the intraspecific structure of Coregonus lavaretus, it is difficult to accept the division into subspecies. It is more practical and purposeful to regard the three groups as forms (Heese, 1985).

The sample examined consisted in $43 \%$ of the maraena, in $29 \%$ of the generosus, and in $28 \%$ of the lavare tus individuals.

2. Number of scales

The scale analysis (Table 3) demonstrated similarity between the lavaretus and maraena individuals. Those belonging to forma generosus have 6 scales more, on the average, along the lateral line, which indirectly evidences the presence of finer scales in this form. The scale formulae of all the three forms are as follows:

$$
\begin{array}{lrl}
\text { lavaretus } & 79-98 & \frac{8-13}{8-11} \\
\text { maraena } & 82-96 & \frac{8-12}{9-13} \\
\text { generosus } & 87-102 & \frac{9-12}{10-14}
\end{array}
$$

3. Length and weight growth

Table 4 and Fig. 3 present data on growth rates of the whitefish forms distinguished. The highest growth rate was observed in the maraena form, while the two other forms grew more slowly and at a rate similar to each other. The difference in growth rate of the maraena and other individuals amounted to about $3-5 \mathrm{~cm}$.

All the three forms showed the highest mean annual increments to occur in the first four years of life, before attaining sexual maturity (Fig. 3), after which time the annual increments dropped markedly.

Data on weight growth vs. fish age (Table 5) set off, too, the maraena individuals as the fastest growing ones. On the other hand, the weight-total length relationship is similar in the maraena and generosus individuals (Fig. 4), the relationship increasing faster informa lavaretus, which presumably resulted from different body proportions or better

\begin{tabular}{|c|c|c|}
\hline lavaretus & $\log$ & $\begin{array}{l}W=2.8976 \log L-1.7546 \\
W=0.017595 L^{2.8976}\end{array}$ \\
\hline maraena & $\log$ & $\begin{array}{l}W=2.9449 \log \mathrm{L}-1.9070 \\
\mathrm{~W}=0.01238 \mathrm{~L} 2.9449\end{array}$ \\
\hline gener & $\log$ & $\begin{array}{l}W=2.3869 \log \mathrm{L}-0.9027 \\
\mathrm{~W}=0.12511 \mathrm{~L} 2.3869\end{array}$ \\
\hline
\end{tabular}
condition during measurements. The logarithmic and exponential equations describing the relationship in the three forms are as follows: 
Total weight (g) growth rate in different whitefish forms

\begin{tabular}{|c|c|c|c|c|c|c|c|c|c|c|c|c|}
\hline \multirow{2}{*}{$\begin{array}{c}\text { form } \\
\text { age group }\end{array}$} & \multicolumn{4}{|c|}{ lavaretus } & \multicolumn{4}{|c|}{ maraena } & \multicolumn{4}{|c|}{ generosus } \\
\hline & $\mathrm{n}$ & range & mean & $\begin{array}{c}\text { mean } \\
\text { annual } \\
\text { increment }\end{array}$ & $\mathrm{n}$ & range & mean & $\begin{array}{c}\text { mean } \\
\text { annual } \\
\text { inctement }\end{array}$ & $\mathrm{n}$ & range & mean & $\begin{array}{c}\text { mean } \\
\text { annual } \\
\text { increment }\end{array}$ \\
\hline I & 5 & $41-78$ & 59 & 59 & 19 & $43-85$ & 64 & 64 & - & - & - & - \\
\hline II & 8 & $180-300$ & 224 & 165 & 17 & $207-390$ & 299 & 235 & 11 & $221-259$ & 240 & - \\
\hline III & 14 . & $480-600$ & 520 & 296 & 24 & $246-706$ & 526 & 227 & 14 & $480-650$ & 555 & 315 \\
\hline IV & 15 & $640-780$ & 710 & 190 & 20 & $665-885$ & 775 & 249 & 7 & $700-1000$ & 850 & 295 \\
\hline V & 13 & $810-1128$ & 919 & 209 & 15 & $925-1175$ & 1050 & 275 & 26 & $970-1128$ & 1049 & 199 \\
\hline VI & 23 & $1190-1310$ & 1250 & 331 & 18 & $1250-1430$ & 1340 & 290 & 23 & $1136-1268$ & 1201 & 152 \\
\hline VII & 16 & $1423-1567$ & 1495 & 245 & 14 & $1597-1663$ & 1630 & 290 & 20 & $1387-1539$ & 1463 & 262 \\
\hline VIII & 5 & $1581-1821$ & 1751 & 256 & 18 & $1798-1992$ & 1895 & 265 & 7 & $1648-1750$ & 1699 & 236 \\
\hline IX & 3 & 1904-2004 & 1954 & 203 & 6 & $2005-2295$ & 2150 & 255 & 1 & 1883 & 1883 & 184 \\
\hline $\mathrm{X}$ & 1 & 2178 & 2178 & 224 & 4 & $2190-2374$ & 2332 & 182 & 1 & 2090 & 2090 & 207 \\
\hline XI & 1 & 2314 & 2314 & 136 & 2 & $2410-2590$ & 2500 & 168 & - & - & - & - \\
\hline XII & - & - & - & - & 1 & 2613 & 2613 & 113 & - & - & - & - \\
\hline
\end{tabular}




\section{Food}

The whitefish food was analysed mostly qualitatively, the food items being ascribed to plankton or benthos (Table 6). The maraena and generosus individuals fed on both the planktonic and benthic organisms, the plankters in the first being less abundant and diverse. On the other hand, no planktonic animals were found in the food of forma lavaretus. Fig. 5 presents differences in food composition.

The diet of larger whitefish (longer than $40 \mathrm{~cm}$ ) included also fish, mainly smelt and nuff, and sporadically the montee eel. Moreover, fish eggs, presumably those of conspecifics, were found in stomachs as well.

Food composition of whitefish studied (frequency of occurrence of principal food groups)

\begin{tabular}{|c|c|c|c|}
\hline From & Plankton & Benthos & Other \\
\hline lavaretus & & $\begin{array}{l}\text { Chironomidae larvae, } \\
\text { Asellus, Chaoborus, Bi- } \\
\text { thynia, Valvata, Piscicola, } \\
\text { Pisidium, Dreissena Ostra- } \\
\text { coda, Chydorus, Alona, } \\
\text { Diptera }\end{array}$ & $\begin{array}{l}\text { shells, sand, detritus - } \\
\text { ruff, eggs, fragments } \\
\text { of vascular plants }\end{array}$ \\
\hline$\%$ & $\therefore \quad 0$ & 86 & 14 \\
\hline maraena & $\begin{array}{l}\text { Daphnia, Mesocy- } \\
\text { clops, Diaptomus, } \\
\text { Leptodora }\end{array}$ & $\begin{array}{l}\text { Sialis, Theodoxus, Chiro- } \\
\text { nomidae, larvae, Asellus, } \\
\text { Chaoborus, Bithinia, } \\
\text { Valvata, Piscidium, } \\
\text { Dreissena, Piscicola, } \\
\text { Ostracoda, Chydorus, } \\
\text { Alona, Diptera }\end{array}$ & $\begin{array}{l}\text { Melosira, Gloeotrichia, } \\
\text { detritus, sand, white- } \\
\text { fish eggs, smelt, ruff, } \\
\text { montee eel }\end{array}$ \\
\hline$\%$ & 13 & 65 & 22 \\
\hline generosus & $\begin{array}{l}\text { Cyclops, Mesocy- } \\
\text { clops, Daphnia, } \\
\text { Bythotrephes, Lep- } \\
\text { todora, Eudiapto- } \\
\text { mus, Leptocerus }\end{array}$ & $\begin{array}{l}\text { Chironomidae larvae, } \\
\text { Asellus, Theodoxus, } \\
\text { Pallasea, Phyllopoda }\end{array}$ & $\begin{array}{l}\text { detritus, sand, shells, } \\
\text { smelt, fragments of } \\
\text { vascular plants }\end{array}$ \\
\hline$\%$ & 61 & 28 & 11 \\
\hline
\end{tabular}




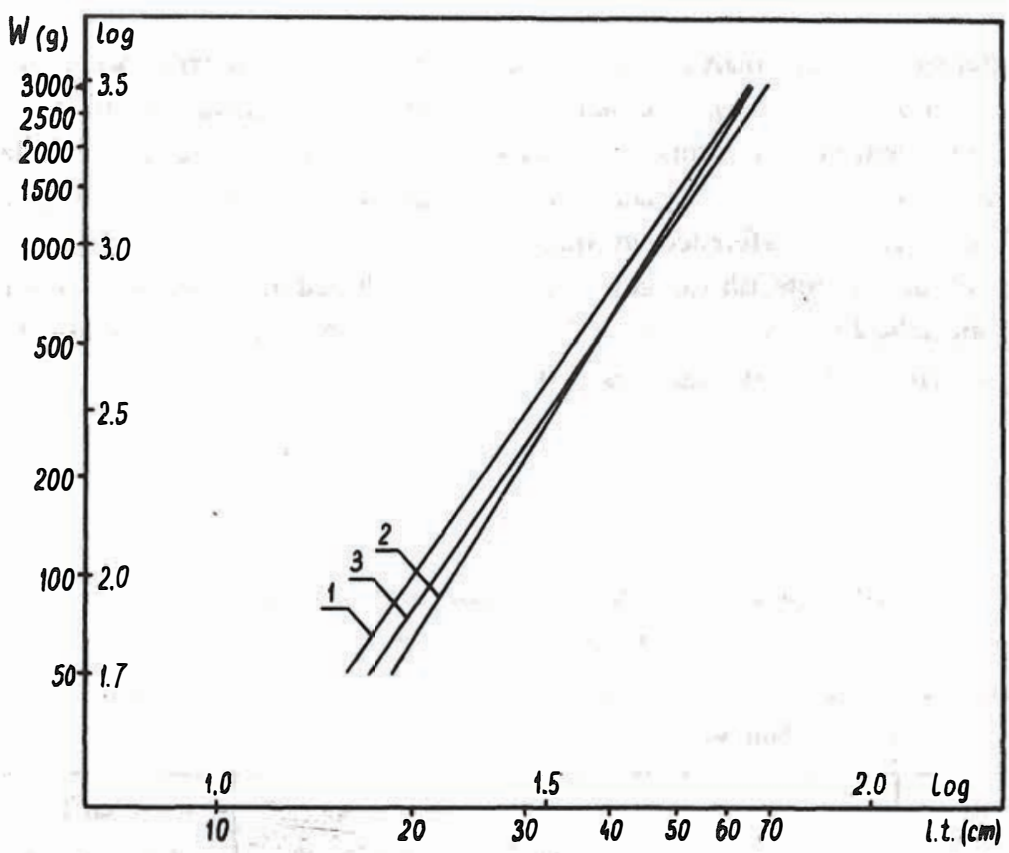

1.ig. 4. Weight growth rate as dependent on total length (1.t.).

$1=f$. lavaretus; $2=f$. maraena; $3=f$. generosus (graph plotted in log scale)

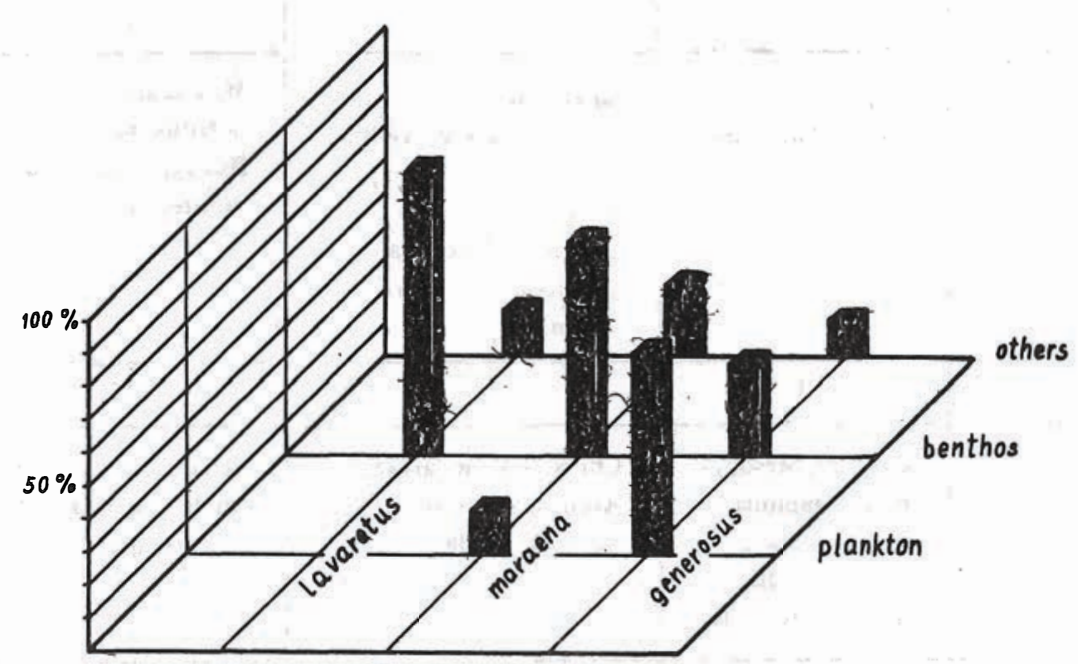

I.ig. 5. Jrequency of occurrence of different food items in various whitefish forms 


\section{DISCUSSION}

Forma maraena is the most interesting whitefish form among those discerned. The form is indigenous in the Lake Miedwie, thus its present extinction is still more regrettable.

The results of studies on the Lake Miedwie whitefish presented evidence a large potential of the Lake for coregonid production. Growth rate of the whitefish forms discussed is one of the highest in Poland, which is mainly an effect of environmental conditions. Marciak (1967), too, considers the habitat as a rather important factor for whitefish growth.

The analysis of the whitefish food composition demonstrates the species, ability to consume diverse food. There was a certain trend toward a dependence of the planktonic to benthic items ratio on the density of the fish filtration apparatus. Stomach contents of the whitefish with the lowest gill raker count (f.lavaretus) lacked plankters. On the other hand, the largest quantities of plankton were found in the fish possessing a dense filtration apparatus (f.generosus). This is then a rather clear indication that the gill raker count determines the domination of planktonic or benthic items in diet. Food availability is another important factor, limited - in the case of whitefish - by water oxygenation. According to Kaj (1955), this is a key factor for whitefish feeding in the Gorzyn lakes. In summer, the whitefish could have been fished with the Peter net within the epilimnion only, while in autumn, after the water column had been mixed, the whitefish were caugint at depths down to $18 \mathrm{~m}$.

Table 7

Comparison of mean gill raker counts and contributions of various whitefish forms in the present study and in Gąsowska (1965)

\begin{tabular}{|l|c|c|c|c|}
\hline \multirow{2}{*}{ Whitefish form } & \multicolumn{2}{|c|}{ Gąsowska (1965) } & \multicolumn{2}{c|}{ Authors dati 1973-1974 } \\
\cline { 2 - 5 } & \% contribution & $\begin{array}{c}\text { mean gill raker } \\
\text { count }\end{array}$ & \% contribution & $\begin{array}{c}\text { mean gill raker } \\
\text { count }\end{array}$ \\
\hline lavaretus & 0.5 & & 28 & 23.6 \\
\hline maraena & 50 & 31.0 & 43 & 29.6 \\
\hline generosus & 49.5 & 39.4 & 29 & 40.3 \\
\hline
\end{tabular}

Table 7 compares the results obtained in the present study with earlier data reported by Gąsowska (1965). The basic difference concerns the respective contributions of the whitefish forms occurring in the Lake, mainly lavaretus and generosus. A comparison of gill raker counts demonstrates that the maraena and generosus forms have retained their specific mean counts. No comparison was possible for forma lavaretus due to the lack of a representative sample in Gąsowska (1965) 
Comparison between Lake Medwie f. maraena and migratory whitefish of Szczecin Lagoon

\begin{tabular}{|l|c|c|c|c|c|c|}
\hline \multirow{2}{*}{ Character } & \multicolumn{3}{|c|}{ f. maraena, Lake Miedwie } & \multicolumn{3}{c|}{$\begin{array}{c}\text { Migratory whitefish, Szczecin } \\
\text { Lagoon (data from Heese, 1986) }\end{array}$} \\
\cline { 2 - 7 } & $\mathrm{n}$ & range & mean & $\mathrm{n}$ & range & mean \\
\hline gill rakers & 159 & $27-35$ & 29.6 & 267 & $22-35$ & 29.0 \\
\hline $\begin{array}{l}\text { scales along } \\
\text { lateral line }\end{array}$ & 159 & $82-96$ & 89.0 & 267 & $80-98$ & 89.1 \\
\hline
\end{tabular}

A number of authors (Svärdson, 1952, 1970; Himberg, 1970; Resetnikov, 1980) stress the fact of hybridisation between various whitefish forms, intermediate values of gill raker count being the effect.

Within the recent years (1983-1985) a migratory form of whitefish spawning in the Szczecin Lagoon was studied (Heese, 1987). The data obtained on gill raker counts and number of scales along the lateral line are similar to those found for the Lake Miedwie forma maraena (Table 8). The Lake is connected with the Lagoon via the river Płonia and Lake Dąbie. One should, however, remember that - according to Pęczalska (1962) - the mean gill raker count in the Szczecin Lagoon whitefish was 26 (the range of 23-33). The data may evidence the introgression of forma maraena to the Szczecin Lagoon whitefish population due to, mainly, stocking operations. A hatchery in Goleniów (located in the vicinity of the Lagoon) produced whitefish hatch and fry within 1962-1972; fertilised eggs were supplied to the hatchery from the Lake Miedwie and the Lagoon, a situation which facilitated mixing of the stocking material.

Additionally, the presence in the Lake Miedwie of forma lavaretus having 22-25 gill rakers is interesting as no population with such a sparse filtration apparatus was recorded in the Szczecin Lagoon. Similarly to the generosus individuals, the form in question had been presumably introduced during earlier stocking operations.

It is the present author's opinion that a next attempt to stock the Lake Miedwie with whitefish should involve mainly forms with dense filtration apparatus. During a prolonged summer stagnation, the benthos-feeding lavaretus individuals suffered of the lack of suitable feeding condition, which was confirmed by poor filling of their stomachs during summer.

\section{REFERENCES}

Berg. L.S., 1948: Ryby presnych vod SSSR i sopredelnych stran. Izd, AN SSSR, T. I, Moskva. (in Russian)

Gąsowska M., 1965: Aktualne formy siei jeziora Miedwie. [Current forms of whitefish in Lake Miedwie ]. Gosp. rybna, 1:3-5. 
Gąsowska M., 1967: Analytic survey of Coregonids of three Polish Lakes: Miedwie, Pełcz and Wielkie Okonińskie. Ann Zool., Warszawa, 24,3: 343-359.

Heese T., 1985: Charakterystyka morfologiczna i biologiczna siei Coregonus। lavaretus (L., 1758) Zatoki Pomorskiej. [Morphological and biological characteristics of whitefish, Coregonus lavaretus (L., 1758) of the Pomeranian Bay. Ph.D.Thesis]. Praca doktorska, Bibl. AR Szczecin.

Heese T., 1987: Morfologia dwóch form plastycznych siei Coregonus lavaretus (L.) występujących w Zatoce Pomorskiej i Zalewie Szczecińskim. [Morphology of two plastic forms of whitefish Coregonus lavaretus (L.) ocourring in the Pomeranian Bayl and Szczecin Lagoon]. Acta Ichthyol. et Pisc. XVII,1: 3-28.

Himberg K.J.M., 1970: A systematic and zoogeographic study of some North European coregonids. In: Biology of Coregonid fishes. Winnipeg, Univ. Manitoba Press: 219-250.

Kaj J., 1955: Sieja jezior Międzychodzkich. [Whitefish of the Międzychód lakes]. PWN, Poznan.

Kaj J., 1962: Salmonidae, Thymallidae, Osmeridae. Klucze do oznaczania kręgowców. Polski, część I - Krągłouste i Ryby, Cyclostomi et Pisces, pod red. M. Gąsowskiej. [Salmonidae, Thymallidae, Osmeridae. Keys to identification vertebrates of Poland. Part 1. Cyclostomates and Fish (Cyclostomi et Pisces]. Edited by M. Gąsowska. PWN Warszawa - Kraków.

Lityński A., 1932: Sieja wigierska. Przyczynek morfologiczno-biologiczny. [The Lake Wigry whitewhish. Adcontribution to its morphology and biology]. Arch. Hydrob. i Ryb., 6: 1-40.

Marciniak Z., '1967: Zasady oceny wzrostu siei. [Principles of whitefish growth evaluation]. Gosp. rybna, 12: 8-10.

Mastyński J., 1986: Coregonidy w jeziorze Miedwie. [Coregonids in Lake Miedwie. In: Proceedings of 13th Conference of Polish Hydrobiologists, Sczecin, 16-19 September 1986].

Pęczalska A., 1962: Badania nad sieją (Coregonus levaretus L.) Zatoki Pomorskiej i Zalewu Szczecińskiego w latach 1956-1958. [Studies on whitefish (Coregonus lavaretus L.) of the Pomeranian Bay and Szczecin Lagoon in 1956-1958]. Prace MIR, 11-A: 287-320.

Pęczalska A., 1966: Sieja Zatoki Pomorskiej (Coregonus lavaretus L.) [The Pomeranian Bay whitefish (Coregonus lavaretus L.). Ph.D.Thesis]. Praca doktorska, Bibl. ART Olsztyn.

Rešetnikov Ju.S., 1980: Ekologija i sistematyka sigovy çh ryb. Izd. Nauka, Moskwa. (in Russian)

Rybak J.I. 1971: Przewodnik do rozpoznawania niektórych bezkręgowych zwierząt słodkowodnych. [A.guide to identification of some freshwater invertebrates]. Zakł. Ekol. PAN, Warszawa.

Stankiewicz E.B., Mutko T., 1978: Od eutrofizacji do degradacji na przykładzie kilku akwenów w woj. szczecińskim. [From eutrophication to degradation as exemplified by several water bodies in the Szczecin District]. Gosp. rybna, 1: 4-7.

Steinmann P., 1951: Monographie der Schweizerischen Koregonen. Teil III. Schweizer. Z. Hydrobiol., 13,1: 54-156.

Svärdson G., 1952: The Coregonid problem. IV. The significance of scales and gill rakers. Rep. Inst. Freshwater Res. Drottningholm, 33: 204-232.

Svärdson G., 1970: Significance of introgression in Coregonid evolution. In: Biology of Coregonid Fishes. Winnipeg, Univ. Manitoba Press, 33-59.

Tadajewski A., Mutko T., 1980: Charakterystyka hydrochemiczna jeziora Miedwie ze szczególnym uwzględnieniem stopnia jego zeutrofizowania. Materiały Sesji Naukowej „Optymalizacja produkcji rolniczej na obszarze zlewni rzeki Płoni z zachowaniem czystości wód jeziora "sedwie". [Hydrochemistry of Lake Miedwie with a particular reference to eutrophication. Conference Proceedings: Optimisation of agricultural production within River/Płonie drainage, with preservation of Lake Miedwie water purity]. Wyd. AR Szczecin: 44-58.

Thienemann A., 1935: Der Schnäpel (Coregonus lavaretus balticus) in Vorpommern. Sonderdruck aus Dohrniana, 14: 85-91.

Wiese A., 1938: Die Grossmaranen Ostpreussens. Fisch. 35: 475-539. 


\section{R. Trzebiatowski, T. Heese, J. Wiszniewski}

\section{FORMY SIEI COREGONUS LAVARETUS (L.) JLZIORA MIIEDWIE}

\section{STRESZCZENIE}

Ryby do badań $(\mathrm{n}=373)$ pobrano $\mathrm{z}$ jeziora Miedwie w okresie od 3.08.1973 do 15.05.1974. W oparciu o liczbę wyrostków filtracyjnych stwierdzono trzy różne formy tego gatunku: lavaretus, maraena i generosus (odpowiednio średnia liczba wyrostków filtracyjnych wynosi 23,6; 29,6 i 40,3). W pobrancj próbic procentowo najliczniej reprezentowana była forma maraena 43\%, następnie generosus $29 \%$ i lavaretus $28 \%$.

Najszybszy wzrost obserwuje się u formy maraena, natomiast formy lavaretus i generosus rosły wolnicj i w podobnym do siebie tempie. Wszystkie trzy formy siei najwyższc średnie przyrosty roczne miały w pierwszych 4 latach życia do osiągnięcia dojrzałości płciowej. Tempo wzrostu omawianych form należy do jednych z najwyższy ch w Polsce, na co głównic wpłynęły warunki środowiska.

Analiza składu zjadanego pokarnı! świadczy o wielożerności siei i możliwości zjadania różnorodnego pokarmu. Sieje o najmniejszej liczbie wyrostków filtracyjnych (f. lavaretus) nie posiadały w badanych żołądkach organizmów planktonowych. Z kolei najwięcej planktonu stwierdzono u ryb z gęstyın aparatem filtracyjnym (f. generosus). Charakter tego odżywiania świadczy o dominacji poszczególnych składników pokarmowych w zależności od ilości wyrostków filtracyjnych.

Prezentowane w oparcowaniu wyniki badań nad sieją jeziora Miedwie należy już dzisiaj uznać za historyczne, gdyż obecnie gatunek ten w omawianym zbiorniku całkowicie zanikł. W 1975 roku miała tu micjsce katastrofa ekologiczna powodująca całkowite odtlenienie wody poniżej $12 \mathrm{~m} \mathrm{i}$ masowe śnięcia sici. Pojedyncze okazy sporadycznie łowiono jeszcze w 1985 r. Stąd wynika znaczenie powyżzzych danych świadczących o możliwościach produkcyjnych w tym akwenie.

Najbardziej interesującą i szczególną formą siei z wyróżnionych jest forma maraena. Forma ta w jeziorze Miedwic ma swoje pierwotne siedlisko i jej obecny zanik jest tym bardziej dotkliwy.

Zdanicm autorów pracy, przy ponownej próbie zarybienia jeziora Miedwie należy przede wszystkim uwzględnić formy siei o dużcj liczbie wyrostków filtracyjnych. Badana forma lavaretus, żywiąca się głównic fauną denną, w czasie przedłużającej się stagnacji letniej nie miała właściwych dla siebie warunków pokarmowych. Potwierdzeniem tego był fakt słabo napełnionych przewodów pokarmowych tej formy w okresie lata.

Authors' address:

Prof. Dr Rajmund Trzebiatowski

Insty tut Akw'akultury i Techniki Rybackiej

Akademia Rolnicza

ul. Kazimierza Królewicza 4

71-550 Szczecin

Polska (Poland) 